\title{
What to Do about Fannie and Freddie: A Primer on Housing Finance Reform
}

\author{
By Jordan Rappaport
}

I

n September 2008, amid collapsing home prices and soaring mortgage defaults, the U.S. government took control of Fannie Mae and Freddie Mac, the two dominant entities in U.S. residential mortgage markets. Specifically, the government placed Fannie and Freddie into a conservatorship, extending each a $\$ 100$ billion line of credit and replacing their CEOs and boards of directors. This conservatorship was meant to be temporary to curtail the risk of financial contagion during the financial crisis, conserve the value of the companies, and return them to safe-and-sound condition. But as of mid-2020, more than 11 years later, the conservatorship persists.

The conservatorship together with other mortgage-finance institutions have been meeting several important goals over the past few years, arguably satisfying most households' mortgage needs and, on balance, supporting financial stability. Even so, almost all policymakers, researchers, and industry advocates agree on the need to move to a system of mortgage finance in which the government plays a less direct role. Such a system might also better achieve certain goals such as holding down mortgage interest rates and boosting incentives to monitor mortgage credit quality.

Jordan Rappaport is a senior economist at the Federal Reserve Bank of Kansas City. This article is on the bank's website at www.KansasCityFed.org 
This primer reviews the current system of mortgage finance and analyzes the key issues policymakers face in reforming it, including what to do with Fannie and Freddie. While policymakers have reached a rough consensus on several key issues, such as allowing the government to continue to help some households finance purchasing homes, they disagree on the share of mortgage lending the government should backstop against widespread defaults and how many companies should have access to the backstop.

Section I reviews the U.S. system of financing mortgages for singlefamily homes in the years leading up to and during the conservatorship. Section II describes some strengths and weaknesses of the current system under the conservatorship. Section III discusses the extent to which the government should backstop residential mortgage lending and the number of companies that should succeed Fannie and Freddie.

\section{The U.S. System of Mortgage Finance}

Fannie Mae-formally, the Federal National Mortgage Association-was established as a federal government agency during the Great Depression to increase the supply of mortgage funds available across the country. Rather than lending to consumers directly, Fannie Mae purchased mortgage loans from private lenders, typically banks, in the "secondary" mortgage market. In doing so, Fannie Mae increased lenders' funds so that they could extend new mortgage loans.

The loans Fannie Mae purchased were limited to those insured by the Federal Housing Administration (FHA), meaning the FHA covered any delinquent payments by borrowers and paid off mortgages in the event of foreclosure. Fannie Mae retained some of the loans it purchased and pooled others together to sell as securities. Private investors in these mortgage-backed securities (MBS) received monthly cash flows based on borrowers' payments of principal and interest on the mortgages in the underlying pool. The FHA insurance, backed by a full-faith U.S. government guarantee, made these securities very low risk and therefore attractive to investors. Following World War II, Fannie also began purchasing loans insured by the recently formed Veterans Administration (VA).

Over the following decades, Fannie Mae went through a series of transformations. Most importantly, in 1968, Congress rechartered 
Fannie as a government-sponsored enterprise (GSE). Henceforth, Fannie Mae would be a for-profit, shareholder-owned company regulated by the Department of Housing and Urban Development, raising funds on public stock and bond markets while retaining its government mandate to increase liquidity in secondary mortgage markets. A new government organization known as Ginnie Mae (formally, the Government National Mortgage Association) took over the purchase and securitization of mortgages insured by the FHA and VA. ${ }^{1}$ Fannie, instead, would purchase only mortgages not insured by the federal government, which it would hold in portfolio. Mortgages eligible for purchase had to meet two legislated requirements: first, the loan principal had to fall below a proscribed maximum; second, borrowers had to either make a down payment above a certain threshold or purchase mortgage insurance that would pay Fannie if the borrowers defaulted. In addition to these requirements, Fannie itself imposed relatively conservative underwriting standards.

Two years later, in 1970, Congress chartered a second housing GSE, Freddie Mac (the Federal Home Loan Mortgage Corporation). Like Fannie, Freddie purchased eligible mortgages from lenders and imposed relatively conservative underwriting standards. But instead of holding these loans in portfolio, Freddie Mac pooled most of them into securities that it sold to investors. In return for a fee, Freddie Mac guaranteed investors that the securities would pay out as scheduled even if borrowers missed payments or defaulted. While Freddie Mac stated explicitly that this guarantee was not backed by the federal government, many investors nevertheless perceived the government's sponsorship and regulation as implying that it would backstop Freddie rather than let it default on its obligations.

Securitizing mortgages proved more profitable than holding them in portfolio, so Fannie shifted to this model during the 1980s, as both its business and that of Freddie soared. The blue bars in Chart 1 show that MBS guaranteed by Fannie or Freddie increased from 7 percent of U.S. single-family mortgage debt in 1980 to 26 percent in 1990 . The green bars, which add loans securitized by Ginnie Mae, show that MBS guaranteed by the three firms rose from 17 percent of single-family mortgage debt in 1980 to 41 percent in 1990. Most remaining singlefamily mortgage debt during the 1980s took the form of individual 


\section{Chart 1}

Outstanding Mortgage Servicing

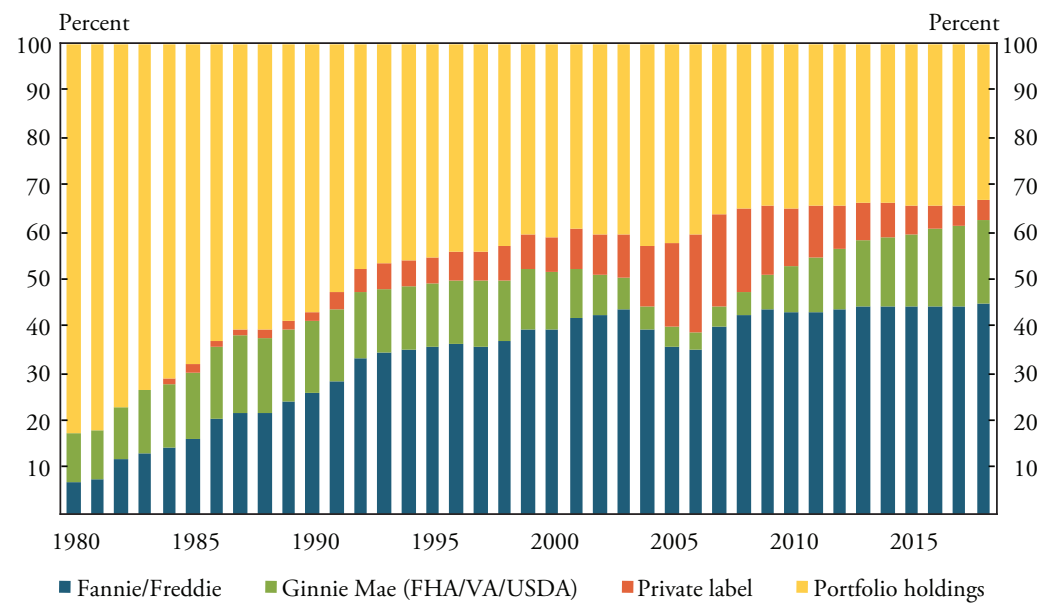

Sources: Fannie Mae, Freddie Mac, Ginnie Mae, Board of Governors of the Federal Reserve System, and Inside Mortgage Finance.

loans held in portfolio by banks and other financial institutions (yellow bars). ${ }^{2}$

The orange bars in Chart 1 show that "private-label" securities became increasingly popular during the 1990s, as Fannie and Freddie's success begot increasing competition from investment banks. Rather than guaranteeing payments, investment banks issued MBS that were split into different tranches of seniority: more junior tranches, which paid a higher interest rate, absorbed any delinquencies and defaults before the more senior tranches. Some of these private-label securities bundled "jumbo" loans_-which had principal above the conforming limit - made to households with good credit. Others bundled "Alt-A" loans to households unable to sufficiently document a steady source of income and "subprime" loans to households with poorer credit. The private-label securities, including their most senior tranches, paid a higher interest rate than Fannie and Freddie securities, compensating investors for the riskiness of the loans and the lack of a perceived government guarantee.

Partly in response to the competition from private investment banks, Fannie and Freddie took on increasing risk during the early 2000s. For example, the share of mortgage loans Fannie and Freddie 
purchased that had down payments of 10 percent or less of the home's appraised value increased substantially from 2003 to 2007, as did the share of mortgages with nonstandard features such as an initial period during which principal payments were not required (Frame and others 2015). At the same time, borrowers began increasingly relying on a second mortgage to make the down payment on a first mortgage, increasing their indebtedness and thus their risk of default (Davis and others 2019). ${ }^{3}$ In addition, Fannie and Freddie bulked up their portfolio holdings of risky Alt-A and subprime MBS, which they judged to be especially profitable. ${ }^{4}$ Notwithstanding this shift to a riskier business strategy, Fannie and Freddie continued to hold relatively shallow capital buffers to absorb losses, rationalized by the low historical default rates of loans they had previously securitized. Defaults remained low during the early 2000s, reflecting fast home price growth propelled in part by relaxed mortgage lending standards.

The undercapitalization of Fannie and Freddie, the increased riskiness of their portfolios, and the increasingly risky loans they guaranteed were made possible by lax regulation and investors' inattention to the firms' creditworthiness. First, Fannie and Freddie's safety-and-soundness regulator at the time, the Office of Federal Housing Enterprise Oversight (OFHEO), lacked the authority to set capital standards or place Fannie and Freddie into bankruptcy. In addition, the OFHEO was funded by congressional appropriations and so subject to influence by elected officials, who typically favored more relaxed lending standards (Frame and others 2015). Second, most investors believed that the federal government would backstop Fannie and Freddie against default, partly reflecting the government's sponsorship and regulatory oversight and partly reflecting that the expected financial damage from a default by Fannie or Freddie made them "too big to fail." This belief in an implicit government backstop dulled investors' incentive to monitor whether Fannie and Freddie could meet their debt and MBS guarantee obligations and thus removed an important incentive for Fannie and Freddie to temper risk-taking. Estimates suggest that without the implicit backstop, Fannie and Freddie would have had to pay interest rates on their debt that were 20 to 40 basis points ( 0.2 to 0.4 percentage point) higher (Frame and others 2015). 
Home prices peaked in mid-2006 and then began sharply contracting in early 2007, eventually provoking a wave of mortgage defaults that threatened Fannie and Freddie's solvency. In response, the government placed both firms into a conservatorship on September 6, 2008. Specifically, Fannie and Freddie were placed under the control of a recently created regulator, the Federal Housing Financing Agency (FHFA), which immediately replaced the chief executives and directors of each firm. The goal of the conservatorship was to ensure Fannie and Freddie would continue to meet their guarantee and debt obligations as well as continue to purchase and securitize residential mortgages. To make this possible, the U.S. Treasury agreed to inject up to $\$ 100$ billion in cash to each enterprise (later doubled to $\$ 200$ billion) as needed to keep them solvent, in effect making the implicit guarantee explicit. In return for these injections, Fannie and Freddie issued senior preferred stock to the Treasury that paid a 10 percent dividend and gave warrants to the Treasury to purchase common stock equivalent to 79.9 percent of each company. The firms also agreed to pay an unspecified fee to the government for its funding commitment.

Over the remainder of 2008 through the first quarter of 2012, Fannie and Freddie together drew $\$ 187.5$ billion from the Treasury. ${ }^{5}$ The firms used a portion of these draws to pay the required dividend; in other words, Fannie and Freddie used injections from the Treasury to pay the Treasury. Partly to stop this circularity, the FHFA modified the preferred stock purchase agreement in mid-2012: instead of paying the 10 percent dividend, Fannie and Freddie would henceforth pay any profits they earned to the Treasury. This "income sweep" also prevented the firms from building a capital base from retained earnings, which became especially relevant as house prices stabilized and then began increasing. As a result of the modified agreement, Fannie and Freddie together paid the Treasury $\$ 301$ billion in cumulative profits through the end of 2019.

Fannie and Freddie remain the two most dominant entities in single-family residential finance, together guaranteeing almost half of newly originated mortgages in 2018. Including loans insured by the FHA, VA, and U.S. Department of Agriculture (USDA), the federal government directly controls entities guaranteeing more than twothirds of single-family residential lending. 


\section{Strengths and Weaknesses of the Current System}

The government's direct control of the majority of residential mortgage funding has concerned policymakers for a variety of reasons, including possible lack of competition, mispricing of credit, inefficiencies, and excessive taxpayer-financed support. However, unwinding the conservatorship has proved challenging. Any mortgage-finance system that replaces it will need to balance five competing goals: meeting households' mortgage credit needs, holding down taxpayer support, supporting financial stability, maintaining the flow of new mortgage credit during financial crises, and improving access to affordable housing for low- and moderate-income (LMI) households. The current system under the conservatorship has several strengths when it comes to meeting these goals; it also has some weaknesses that reforms may be able to address.

\section{Meeting households' mortgage credit needs}

The current system of U.S. mortgage finance under the conservatorship and government-insured lending appears, on balance, to be meeting the mortgage needs of most middle-income households. In particular, it lowers interest rates on backstopped mortgages, contributes to the viability of long-term fixed-rate mortgages, and arguably lets most households with at least moderate creditworthiness access mortgage borrowing. To be sure, high housing prices have made purchasing a home a steep financial challenge. But down-payment requirements for FHA loans are low, making the affordability of monthly payments the primary borrowing constraint.

One way the current system lowers mortgage interest rates is by eliminating default risk. Specifically, the full-faith U.S. government backstop drives high demand for agency MBS—those guaranteed by Fannie, Freddie, or Ginnie- by risk-adverse investors such as insurance firms and foreign central banks. This high demand increases the market value of individual mortgages eligible to be included in the underlying pools, in turn allowing lenders to offer lower interest rates to households. When credit markets are functioning normally, this channel is estimated to lower interest rates on conforming mortgages by 30 basis points relative to rates on ineligible mortgages (Scharfstein and Swagel 2016; Frame and others 2015). During periods of financial stress, 
this channel lowers relative interest rates on conforming mortgages by somewhat more.

In eliminating default risk, the backstop also lowers borrower interest rates by increasing the market liquidity of agency securities. The liquidity of a market - the ease of matching buyers and sellers-depends on the substitutability of the traded securities. For some securities, such as a specific company's common stock, the traded shares are identical and thus considered perfect substitutes. In contrast, agency MBS with the same identifying characteristics-such as the specific guarantor (Fannie, Freddie, or Ginnie), interest rate on face value, and maturity_are not identical: instead, each security represents a different mortgage pool made up of multiple individual loans. By eliminating default risk, the backstop allows investors to trade agency MBS with the same identifying characteristics without scrutinizing the credit quality of underlying pools. The resulting substitutability has been sufficiently high to make the agency MBS market one of the most liquid in the world. ${ }^{6}$ Chart 2 shows that the average daily trading volume of agency MBS, a measure of liquidity, dwarfs the daily volume of U.S. corporate and municipal securities. Estimates suggest that this high liquidity lowers borrower interest rates by 10 to 25 basis points during normal times and by somewhat more during times of financial stress (Vickery and Wright 2013).

In addition to lowering interest rates, the high liquidity of the agency market also contributes to the viability of long-term fixedrate mortgages, which are far and away the most popular mortgage type in the United States but are widely available in only one other country, Denmark (Wachter and Tracy 2016; Wachter 2018). For a depository institution, lending at a fixed interest rate for a long duration, such as 30 years, incurs high risk: rising rates can considerably lower the value of such loans, thereby eroding the depository's capital base. An important feature of long-term fixed-rate mortgages in the United States-borrowers' ability to pay down principal before scheduled without a penalty - exacerbates this interest rate risk. Because of the prepay option, borrowers often refinance their mortgages following declines in interest rates, eliminating lenders' potential to profit from downswings. However, the high liquidity of the agency market allows U.S. lenders to immediately and inexpensively offload interest-rate and 


\section{Chart 2}

Average Daily Trading Volume (2015-19)

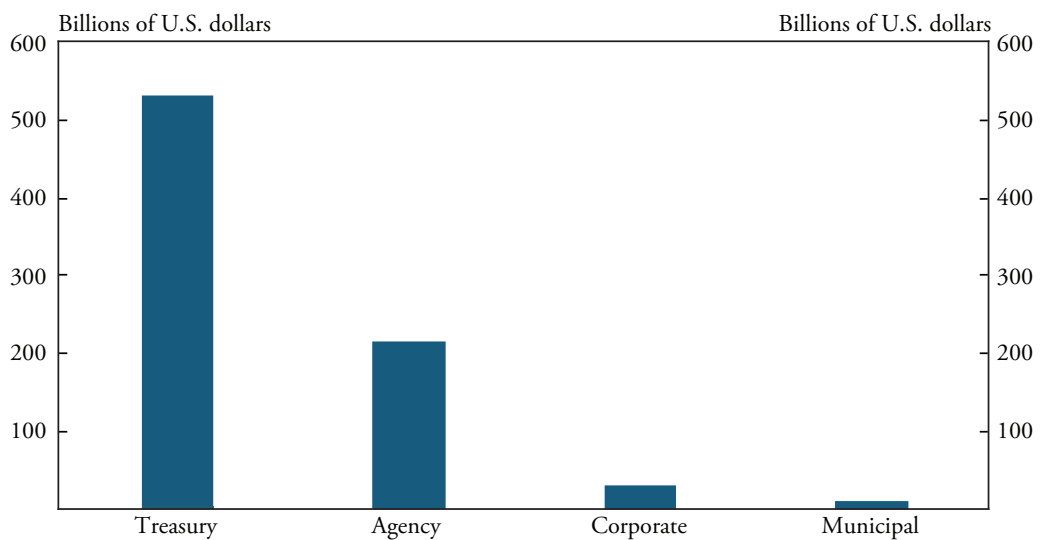

Sources: Financial Industry Regulatory Authority Trade Reporting and Compliance Engine, Securities Industry and Financial Markets Association, Federal Reserve Bank of New York, and Municipal Securities Rulemaking Board Electronic Municipal Market Access.

prepayment risks, boosting lenders' willingness to originate long-term fixed-rate mortgages (Fuster and Vickery 2015; Kanojia and Grant 2016). In contrast, mortgages in almost all other countries are characterized by shorter maturities, variable interest rates, and significant penalties for early payoff.

Finally, middle-income households arguably retain ample access to mortgage credit under the current system, though not necessarily because of the government backstop. In 2019, for example, 72 percent of U.S. adults with a credit history had sufficient credit to qualify for a mortgage (Housing Finance Policy Center 2020; Dornhelm 2019). ${ }^{7}$ Similarly, income requirements have remained moderate relative to loan amounts, allowing households to take on considerable debt. For example, the median debt service-to-income (DTI) ratio of households that purchased a home in 2019-the sum of monthly payments on all of a household's borrowing relative to the household's pre-tax monthly income-was 39 percent (Housing Finance Policy Center 2020). Down-payment requirements have also remained moderate relative to home purchase prices. The median cash down payment in 2019 was 6 percent of a home's purchase price, and loans insured by the FHA 
required a down payment of only 3.5 percent (Housing Finance Policy Center 2020). ${ }^{8}$

A possible weakness of the current system's ability to meet households' mortgage needs is its lack of competition. The government directly controls all of the agencies with access to its backstop, dulling their incentives to compete. A lack of competition may allow Fannie and Freddie to operate inefficiently, increasing guarantee fees paid by lenders, and, in turn, increasing interest rates as lenders pass these fees on to borrowers. Moreover, a lack of competition may allow Fannie and Freddie to become complacent, depressing the innovation of new mortgage products. ${ }^{9}$

\section{Minimizing taxpayer-financed support}

The current system has had mixed success achieving a second key goal of mortgage finance: minimizing taxpayer-financed spending, especially by reducing the collective liability associated with widespread mortgage defaults. The FHA has largely been successful in controlling costs to the taxpayer. Due to the insurance reserve it maintains, funded by an upfront fee on mortgage originations and a continuing annual fee on unpaid balances, the FHA has only needed to draw from the Treasury once-in 2013 for a relatively modest $\$ 1.7$ billion-to meet its expected losses. But Fannie and Freddie have been less successful in achieving this goal. Together, the two agencies drew more than $\$ 187$ billion from the Treasury during the financial crisis. While Fannie and Freddie have since paid the government more than $\$ 300$ billion in dividend payments, the Treasury continues to guarantee $\$ 5$ trillion of their outstanding single-family MBS.

In recent years, the FHFA has directed Fannie and Freddie to put in place buffers that can absorb large losses. To do so, in 2013 Fannie and Freddie began contracting with private investors, reinsurance companies, and lending banks to cover losses when mortgages in the pools backing MBS default. These "credit risk transfers" (CRTs) include securities Fannie and Freddie sell to private investors, from whom they receive principal payments when mortgages default; reinsurance, which Fannie and Freddie purchase on pools of mortgages; and lender recourse, in which the originators of mortgages retain a portion of the default risk. $^{10}$ 
However, as of the end of 2019, the value of CRTs for single-family mortgages was only about 2 percent of Fannie and Freddie's outstanding guarantees, which is unlikely to cover losses in the event of widespread mortgage defaults. ${ }^{11}$ During the Great Recession, Fannie and Freddie's losses on single-family mortgages approximated 5 percent of guaranteed value. Taking into account the higher credit quality of recently securitized single-family mortgages, a crisis similar in magnitude to $2007-10$ would likely entail losses approximating 3 percent of guaranteed value (Goodman and Zhu 2013). ${ }^{12}$ Moreover, during periods of financial stress, investor demand for CRTs is likely to wane, forcing Fannie and Freddie to rely primarily on their own capital to make new guarantees.

\section{Financial stability}

The current mortgage-finance system also has some strengths in addressing the goal of financial stability. Most importantly, the full-faith government guarantee of MBS issued by Fannie and Freddie and loans insured by the FHA, VA, or USDA - together with their high combined market share-greatly diminishes the possibility that widespread mortgage defaults would seize up financial markets. The vast aggregate value of U.S. residential mortgage debt, approximately $\$ 11$ trillion in 2018, is held in large quantities by numerous financial institutions. During periods when mortgages are rapidly defaulting, investors may fear the solvency of financial institutions holding considerable mortgage debt and thus be less willing to trade with them. These fears can quickly multiply to include, for example, the solvency of financial institutions that hold little mortgage debt themselves but lend to other institutions that do. Concerns about financial markets seizing in this manner helped drive the Treasury's 2008 decision to rescue Fannie and Freddie. ${ }^{13}$ Backstopping a large share of single-family lending lowers the amount of risky mortgage assets held by financial institutions, making markets less likely to seize.

A potential weakness of the current system in terms of financial stability are the dulled incentives to monitor Fannie and Freddie's credit quality (described in Section I). However, the credit quality of Fannie and Freddie's loan pools as of mid-2020 appear to remain high. One reason for this relatively high credit quality may be the political pressure to avoid another rescue and the associated careful scrutiny by the 
FHFA. A second reason may be careful scrutiny by investors in Fannie and Freddie's CRTs. A third reason may be lenders' caution to avoid liabilities for poor underwriting, which regulators imposed following the housing crisis.

\section{Maintaining the flow of new mortgage credit during periods of financial stress}

Another strength of the current system is that the government backstop critically contributes to keeping new mortgage credit flowing when financial markets are stressed, helping to stave off a collapse of residential investment. Maintaining the flow of mortgage credit also helps transmit monetary policy easing, allowing homeowners to refinance at lower interest rates. Currently, backstopped lending can quickly scale up to meet most demand for mortgage lending. During the financial crisis, mortgages insured by the FHA, VA, or USDA, together with mortgages securitized by Fannie or Freddie, nearly doubled in value. Chart 3 shows that from 2006 to 2009, the share of origination value accounted for by these mortgages jumped from 35 to 97 percent. ${ }^{14}$

A corresponding weakness, however, is that a significant share of the ramped-up lending during times of financial stress may be for unduly risky transactions. For example, Fannie and Freddie significantly increased mortgage purchases in the year leading up to the financial crisis to replace withdrawn funding from other channels. Loans with approximately 12 percent of the value of the ramped-up purchases eventually defaulted, up from less than 2 percent of the value of loans purchased by Fannie and Freddie in each year from 1999 through 2002 (Goodman and Zhu 2013).

\section{Access to affordable housing}

Finally, the current system of backstopped lending provides some support for affordable housing for LMI households. The FHA, for example, has historically focused on insuring loans to first-time homebuyers, LMI households, and households with credit histories that make them ineligible for Fannie and Freddie securitization (Congressional Research Service 2019). For these mortgages, the FHA requires a down payment of just 3.5 percent. In addition, Fannie and Freddie have long had to meet annual affordable housing goals specifying a minimum share of securitized mortgages that fund the purchase of single-family 


\section{Chart 3}

Newly Originated Single-Family Mortgages

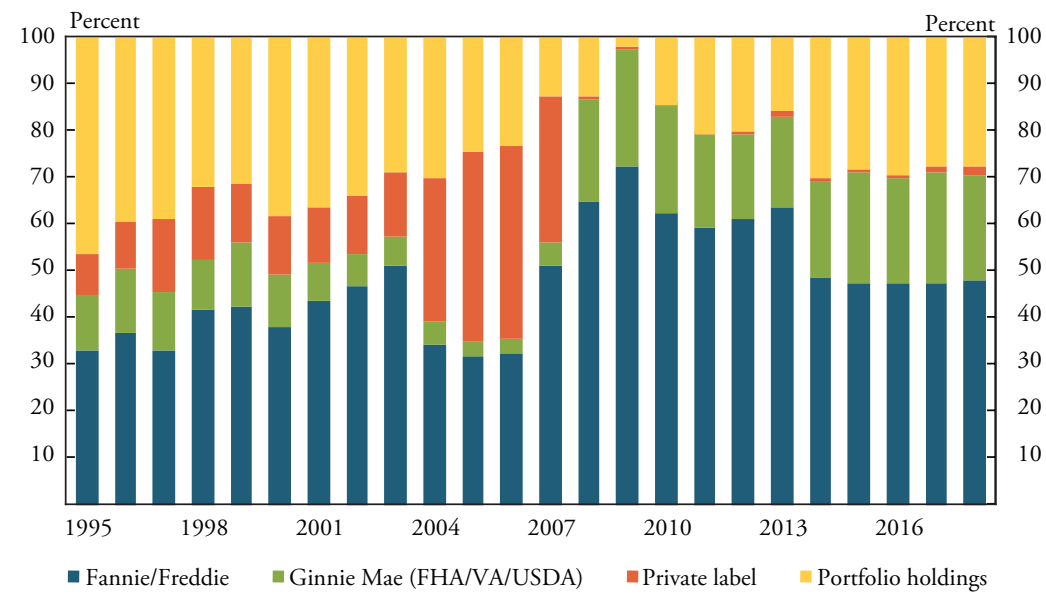

Sources: Fannie Mae, Freddie Mac, FHA, VA, USDA, private mortgage insurers, and Inside Mortgage Finance.

homes occupied by LMI households or located in LMI neighborhoods. ${ }^{15}$ In 2015, Fannie and Freddie also began collecting a small fee for use by government agencies supporting affordable housing. In 2016, they were obligated with a "duty to serve" LMI households in several underserved markets, for example by encouraging lenders to extend mortgage financing and liaising with housing development organizations. ${ }^{16}$

Despite this support, the success of the current mortgage-finance system in improving access to affordable housing by LMI households is unclear. On the one hand, FHA insurance and guarantees by Fannie and Freddie have helped millions of LMI households obtain mortgage financing. On the other hand, single-family home prices remain high for many households, in part reflecting the current system's widespread access to mortgage financing. ${ }^{17}$ Renting an apartment is typically less expensive and thus may be a better option for many LMI households. Lending programs focused on increasing the supply of less-expensive rental apartments may be more effective in improving LMI households' access to affordable housing than lending programs focused on improving LMI households' access to mortgage financing. The FHA, Fannie, and Freddie currently have a number of such programs. 


\section{Reforming Mortgage Finance}

Many of the strengths of the current system of mortgage financeincluding relatively low borrower interest rates, the widespread availability of long-term fixed-rate mortgages, and the continued flow of new credit during periods of financial stress — at least partly depend on the government backstop. Thus, any plan to end the conservatorship will likely retain at least a portion of it. However, questions remain over the appropriate "footprint" of the government backstop as well as how many guarantors_entities such as Fannie and Freddie that guarantee monthly MBS payments to bondholders-should have access to it. The answers to these questions will determine how successful any new system of mortgage finance will be in meeting the five goals discussed in the previous section.

\section{The backstop footprint}

A broad consensus holds that the government should continue to backstop at least some residential mortgage debt (Wachter 2018; Bright and DeMarco 2016; Wallison and Pinto 2018; Fisher and others 2018). But policymakers disagree on the ideal size of the backstop footprint. The current footprint constitutes mortgage-backed securities guaranteed by Fannie and Freddie as well as government-insured lending via the FHA, VA, or USDA. Most remaining residential mortgages are either held in portfolio by financial institutions or securitized in privatelabel offerings.

The size of the backstop footprint relative to other mortgage lending is primarily determined by three factors: eligibility criteria for backstopped loans, capital requirements for existing or new guarantors, and fees the government charges guarantors, lenders, and households for access to the backstop. Tight eligibility criteria, high capital requirements, and high government fees narrow the footprint. Relaxed eligibility criteria, low capital requirements, and low government fees broaden it. The three factors indirectly affect mortgage-finance goals by increasing or decreasing the size of the footprint. However, they each also directly affect mortgage-finance goals, possibly offsetting their indirect effects through the size of the footprint. 
Eligibility criteria help determine the backstop footprint by including or excluding specific types of households, risk profiles, and loan purposes in backstopped lending. Some reformers have proposed adjusting eligibility criteria to explicitly limit the backstop footprint-for example, by excluding loans to purchase a vacation home, purchase a home as an investment, or refinance an existing mortgage while increasing the loan principal.

Capital requirements and government fees also help determine the backstop footprint by making backstopped lending more or less competitive relative to non-backstopped lending. Higher capital requirements and government fees increase the charges Fannie and Freddie collect from borrower payments before passing the remaining cash flow on to investors; these higher charges are, in turn, passed on to individual borrowers in the form of higher interest rates. Higher interest rates make backstopped loans less competitive, thereby decreasing their market share. Similarly, higher insurance fees on mortgages backed by the FHA, VA, or USDA increase their effective cost to borrowers, lowering the competitiveness of these loans relative to loans funded through non-backstopped channels, thereby decreasing their market share.

As noted in the previous section, a broad government backstop contributes positively to several mortgage-finance goals. First, a broad backstop implies that a large share of homeowners enjoy the lower mortgage interest rates made possible by the government guarantee. Second, a broad backstop helps maintain the widespread availability of long-term fixed-rate mortgages. Third, a broad backstop has sufficient baseline capacity to quickly ramp up funding when other channels of mortgage credit dry up, thereby keeping new mortgage credit flowing during a financial crisis. Fourth, a broad backstop supports financial stability by lowering investors' aggregate exposure to widespread mortgage defaults.

However, policymakers may prefer a somewhat smaller footprint to encourage competition with respect to innovation and interest rates, thereby better meeting households' mortgage needs. This competition may be among guarantors and government agencies within the backstop footprint, among private financial firms operating outside the footprint, and between those operating inside the footprint and those operating outside of it. An especially broad footprint would limit 
competition only to guarantors and government agencies. An especially narrow footprint would limit competition only to financial firms. The ideal footprint probably lies between these extremes, allowing for all three forms of competition.

An intermediate-sized footprint, rather than a narrow one, may also better meet the goal of limiting taxpayer-funded spending on mortgage finance. Although a narrow footprint would minimize explicitly obligated government outlays, it may on net lead to greater total outlays in the event of a financial crisis. In 2008, for example, the threat of severe financial consequences motivated the government to rescue Fannie and Freddie even though it was not obligated to do so. Expectations of a similar government rescue may undermine the future incentive of investors and originators to monitor credit risk outside the explicit footprint. A broader explicit footprint that lowers the amount of mortgage debt remaining outside of it would lessen the financial damage from widespread defaults on this remaining debt. Lower damage increases the credibility that the government will refrain from rescuing investors in non-backstopped mortgages. Such investors thus have greater incentive to scrutinize loan quality, in turn causing originators to apply higher credit standards and lessening the probability of widespread defaults. In addition, keeping the backstop explicit, as under the conservatorship, rather than implicit, as it was previously, would allow the government to charge guarantors a fee for providing it, thereby limiting net taxpayer outlays.

The three determinants of the backstop footprint-eligibility criteria, capital requirements, and government fees-also have their own, independent effects on mortgage-finance goals that may work in the opposite direction of their indirect effects through the size of the footprint. For example, tighter eligibility criteria for loans included in backstopped MBS may directly increase financial stability by requiring characteristics that make default less likely, such as a high credit score, large down payment, and low ratio of debt payments to income. But as described previously, tighter eligibility criteria also decrease the size of the backstop footprint, possibly lowering financial stability indirectly. Similarly, deep capital buffers allow guarantors to absorb widespread defaults, strengthening financial stability and lowering expected taxpayer support. But deep capital buffers also make backstopped funding more expensive 
and so diminish the backstop footprint, possibly contributing to lower stability and higher taxpayer support. A consensus view on balancing this latter tension is that capital buffers should be sufficiently deep to absorb losses under almost all circumstances, leaving the government backstop to cover only "catastrophic" risk such as a surge in borrower defaults similar to what occurred in 2007-10 (Wachter and Tracy 2016; Scharfstein and Swagel 2016).

\section{The number of guarantors}

Several reform proposals seek to spur additional competition within the backstop footprint by increasing the number of guarantors. ${ }^{18}$ Doing so, however, potentially threatens the current system's high liquidity, undermining some of its key strengths. The liquidity of an asset partly depends on the value of the asset that is outstanding and the number of investors who own it. For example, Fannie Mae's MBS have historically traded at a slight premium to Freddie Mac's MBS, reflecting an outstanding value that has remained about 50 percent larger (Layton 2019).

One way to avoid decreased liquidity is to make different guarantors' MBS almost perfectly substitutable, allowing them to be traded interchangeably (that is, without knowing the identity of the guarantor). Fannie and Freddie, at the direction of the FHFA, achieved this interchangeability in mid-2019. For new guarantors to achieve the same interchangeability, they would also need to eliminate default risk (as described in Section II). In addition, new guarantors would need to closely align the prepayment risk of their securities with those of Fannie and Freddie - that is, the probability that borrowers will refinance after interest rates decline, hurting the return to investors. If the prepayment risk instead significantly differs among guarantors' securities, investors will demand to know the identity of the guarantor before purchasing an MBS.

Maintaining interchangeability with just Fannie and Freddie as guarantors presents a considerable challenge. To help do so, the FHFA closely monitors prepayment rates and issues guidance on pooling practices (FHFA 2019a, 2019b). Maintaining interchangeability among even a few more guarantors may not be possible, especially if the guarantors differentiate themselves by focusing their purchases on mortgages originated in specific lending markets across which prepayment 
risks diverge (Wachter 2018). For example, prepayment rates may vary by geographic region, reflecting differences in home price movements and borrower demographics. Indeed, the challenge of maintaining interchangeability has contributed to reform proposals calling for a single guarantor to succeed Freddie and Fannie, which would purchase government reinsurance against systematic credit events and be closely regulated along the lines of a monopoly utility (Mosser, Tracy, and Wright 2013; Parrott and others 2016; Wachter and McCoy 2016).

A possible alternative way to maintain high liquidity with multiple guarantors is to combine mortgage pools created by each into a single traded MBS, similar to how Ginnie Mae securitizes loans insured by the FHA, VA, or USDA (Bright and DeMarco 2016). In this context, it is helpful to think of the individual guarantors as issuers of pooled mortgages, which they originate themselves or purchase from other lenders. Each month, hundreds of these issuers contribute mortgage pools that Ginnie Mae bundles into a single MBS and prorates back to the issuers to sell. The issuers service the mortgages they pool, collecting monthly principal and interest payments from borrowers and remitting them to holders of the bundled Ginnie MBS. Like Fannie and Freddie, the issuers promise to make such remittances regardless of whether the borrowers pay. Ginnie Mae provides a second-level guarantee to make these remittances in case issuers fail to do so. The issuers and Ginnie Mae can hold relatively shallow capital buffers compared with Fannie and Freddie because they need only to temporarily cover cash shortfalls until either borrowers fix their arrears or the insuring government agency covers the missed payments and purchases the defaulted mortgage.

This system of multiple issuers providing a first-level guarantee and a bundling organization providing a second-level one could be adapted to bundle pools of uninsured mortgages. To do so successfully, issuers and bundling organizations would need to hold considerably larger capital buffers than under the current Ginnie Mae system, reflecting the requirements to permanently rather than temporarily cover borrower arrears and to purchase defaulted mortgages. The deeper capital buffers would likely need to include significant credit transfers to additional private investors, reinsurance companies, and lending banks. A government backstop of the bundled MBS would serve as a third-level guarantee that completely eliminates default risk. ${ }^{19}$ 
The ideal number of guarantors thus depends on whether guarantors issue MBS that are sufficiently substitutable to be interchangeable or instead issue pools of mortgages that a second-level guarantor bundles into a single MBS. The first option, which would likely require no more than a few guarantors, has the advantage of being similar to the present system, thus minimizing possible disruptions and unforeseen consequences. The second option, which would allow for numerous first-level guarantors, promises more competition while achieving perfect substitutability in the secondary market. An intermediate solution-with a moderate number of guarantors issuing MBS - is unlikely to be successful, as such a system would struggle to achieve interchangeability, thereby diminishing liquidity, increasing borrower interest rates, and possibly threatening the widespread availability of fixed-rate long-term mortgages.

\section{Conclusion}

More than 11 years after the onset of the 2007-08 financial crisis, the U.S. government continues to directly control the two most dominant firms in U.S. residential markets, Fannie Mae and Freddie Mac. Including the activity of the FHA, VA, and USDA, the U.S. government currently backstops more than two-thirds of newly originated single-family mortgages. Although the current setup appears on balance to meet households' mortgage needs, a reformed system of mortgage finance may be better able to achieve certain goals, including holding down mortgage interest rates and lowering expected taxpayer support.

In balancing goals, proposed reforms must address two key questions: how broadly the backstop footprint should extend and how many guarantors it should include. An intermediate-sized footprint will likely maintain many of the strengths of the current system while encouraging competition with respect to innovation and interest rates. The number of guarantors is more difficult to determine. If these guarantors continue to issue their own MBS, the number will need to be limited to maintain the present system's high liquidity. This option would also minimize the risks associated with large-scale reforms. However, if guarantors issue mortgage pools that are bundled into a single MBS, many more guarantors could be accommodated, maintaining high liquidity while possibly increasing competition with respect to innovation and interest rates. 
Of course, reforms may also address several other concerns, from improving LMI households' access to affordable housing, to implementing and enforcing regulation, to smoothing the transition to the reformed system. Reaching legislative consensus on how to address these concerns while meeting households' mortgage credit needs, holding down taxpayer support, supporting financial stability, and maintaining the flow of new mortgage credit during financial crises represents a steep challenge, especially to the extent that the current setup is perceived to be working satisfactorily. For this reason, the system of mortgage finance that emerges after the conservatorship may look similar to the current setup. 


\section{Endnotes}

${ }^{1}$ Ginnie Mae began securitizing mortgages insured by the U.S. Department of Agriculture Rural Housing Service in the mid-1990s. It also currently securitizes a small number of mortgages insured by the Department of Housing and Urban Development's Office of Public and Indian Housing.

${ }^{2}$ Single-family homes are those in which a physical structure includes only one housing unit. Physical structures are considered distinct from each other if they are separated by a ground-to-roof wall and do not share heating, air-conditioning, and other utilities. Thus, some row houses and townhouses are considered single family. Fannie and Freddie classify some MBS as single family that include mortgages on housing structures with two to four units and mortgages on individual condominium and cooperative units in multifamily buildings.

${ }^{3} \mathrm{~A}$ secondary mortgage is subordinate to a first mortgage in the sense that any proceeds from the sale of a foreclosed home go first to pay off the primary mortgage. However, a homeowner's decision to default typically depends on the combined servicing costs and unpaid principal of both mortgages.

${ }^{4}$ Strong evidence supports that profitability was the main motivation for Fannie and Freddie's purchases of Alt-A and subprime MBS (Financial Crisis Inquiry Commission 2011). However, Wallison (2011) presents a dissenting view, suggesting the purchases were primarily to meet affordable housing goals set by Fannie and Freddie's regulator.

${ }^{5}$ Fannie Mae drew down an additional \$3.7 billion in 2017.

${ }^{6}$ The agency market is made up of a number of submarkets. Until recently, Fannie, Freddie, and Ginnie MBS traded in separate submarkets. (Starting in mid-2019, newly issued Fannie and Freddie MBS traded on the same market.) Each of these submarkets is further divided based on MBS maturity $(15,20$, or 30 years) and coupon rate (interest rate on the face value of the MBS, denominated in 50 basis point increments).

${ }^{7}$ Lenders typically use FICO scores as a measure of a person's creditworthiness. The 10th percentile FICO score on newly originated mortgages to purchase a home, which I use as a lower-bound measure of the creditworthiness to qualify for a mortgage, hovered near 650 from 2014 through 2019 (Housing Finance Policy Center 2020). Among persons with sufficient previous commercial borrowing to calculate a FICO score, 72 percent received a score of 650 or higher in 2019 (Dornhelm 2019). A large share of those with scores below 650 had significant credit blemishes such as having been at least 90 days late over the previous two years on a credit card, auto finance, or real estate loan.

${ }^{8}$ The cash down-payment median of 6 percent in 2019 corresponds to a combined loan-to-value (LTV) median of 94 percent. The combined LTV measures the sum of the principal borrowed from first and second mortgages relative to the purchase price of a home. 
${ }^{9}$ To be sure, several important innovations took place during the conservatorship. For example, Fannie and Freddie introduced a new investment product in 2013 that let them transfer a significant portion of MBS credit risk to private investors.

${ }^{10}$ The principal payments from CRT investors are pre-funded in the sense that Fannie and Freddie reduce future cash flow payments to investors rather than actually collecting new funds.

${ }^{11}$ As of the fourth quarter of 2019, Freddie Mac had in force CRTs equal to 2.3 percent of its outstanding single-family MBS (Freddie Mac 2020). Data to calculate the comparable 2019 coverage for Fannie Mae were not available. From 2013 to 2018, cumulative CRTs on single-family mortgages equaled 2.1 percent of Freddie's single-family MBS issuance and 1.5 percent of Fannie's singlefamily MBS issuance, with a combined share of 1.7 percent. But a portion of these CRTs and the corresponding mortgage pools was paid down during this period. In 2018, Freddie and Fannie transferred credit risk equal to 3.6 percent and 2.4 percent, respectively, of their single-family MBS issuance, implying a combined share of 2.8 percent (FHFA 2019c).

${ }^{12}$ Estimated losses are for mortgages securitized in 2007, the vintage that performed worst.

${ }^{13}$ Following the escalation of the COVID-19 pandemic in February 2020, fears that agency MBS would default appear to have been minimal. While the interest-rate spread of agency MBS over matched-duration Treasuries spiked in mid-March, this largely reflected short-term liquidity conditions as bond funds sold off a wide range of assets to meet investor redemptions. As of early May, agency MBS spreads have fallen back to their level prior to the pandemic. The government backstop has likely played an important role in preventing a longerterm increase in the agency spread, as have large-scale purchases of agency MBS by the Federal Reserve.

${ }^{14}$ The extent to which the government backstop is keeping new mortgage credit flowing during the COVID-19 pandemic is less clear. Surveys suggest that credit standards for mortgages eligible to be insured by the FHA or for purchase by Fannie and Freddie have tightened, though by considerably less than for loans with principal above the eligibility limit. The tightening for eligible mortgages partly reflects increased uncertainty about households' income rather than financing conditions per se. It also partly reflects government mandates that allow borrowers of mortgages insured by FHA or securitized by Fannie or Freddie to receive forbearance on monthly payments of principal and interest. Firms that service the loans in Fannie and Freddie pools, many of which originate such loans, must cover skipped payments for four months before Fannie or Freddie will. Originators intending to sell loans to Fannie and Freddie face the risk that new loans will go into forbearance before they do, in which case the originator would either incur losses from the missed payments or pay a significant penalty fee when selling such loans to Fannie or Freddie. 
${ }^{15}$ For example, one goal for $2018-20$ is that 24 percent of the mortgages in single-family pools be to families with income no greater than 80 percent of their area's median income. Another goal is that 6 percent of such mortgages be to families with incomes no greater than 50 percent of their area's median income.

${ }^{16}$ The relevant legislation designated three underserved markets: manufactured housing, affordable housing preservation, and rural housing.

${ }^{17}$ Home prices would likely be lower if mortgage financing were less readily available (Fisher and others 2018; Wallison and Pinto 2018).

${ }^{18}$ For example, the "Housing Finance Reform and Taxpayer Protection Act of 2014" proposes replacing Fannie and Freddie with multiple private guarantors, whose MBS would be backed by a government-run insurance fund. The Mortgage Bankers Association (2017) recommends rechartering Fannie and Freddie as the first of multiple regulated utilities issuing interchangeable MBS.

${ }^{19} \mathrm{~A}$ drawback of such a system is that the prepayment risk of the single security depends on the prepayment risk of each of the underlying MBS, making the security vulnerable to the pooling practices of individual guarantors. For example, some lender/guarantors of VA-insured loans encourage borrowers to rapidly refinance to generate origination fees. The associated high prepayment rates depress the price of Ginnie Mae securities, contributing to higher interest rates on all loans insured by the FHA, VA, and USDA (Bright 2018; Goodman, Golding, and Neal 2019). 


\section{References}

Bright, Michael R. 2018. "Testimony before the Committee on Veterans Affairs, Subcommittee on Economic Opportunity.” Washington, DC, January 10.

Bright, Michael, and Ed DeMarco. 2016. "Toward a New Secondary Mortgage Market.” Milken Institute, Viewpoints, September.

Congressional Research Service. 2019. "FHA-Insured Home Loans: An Overview." Washington, DC, January 16.

- 2016. "The Housing Trust Fund: Background and Issues." Washington, DC, May 24.

Davis, Morris A., William D. Larson, Stephen D. Oliner, and Benjamin R. Smith. 2019. "A Quarter Century of Mortgage Risk.” American Enterprise Institute, working paper 2019-04, February.

Dornhelm, Ethan. 2019. “Average U.S. FICO Score Ticks Up to 706.” FICO Blog, September 10.

Fannie Mae. 2020. Form 10-K: Annual Report for the Fiscal Year Ended December 31, 2019. Washington, DC: United States Securities and Exchange Commission.

FHFA (Federal Housing Finance Authority). 2019a. "Enterprise UMBS Pooling Practices Request for Input." Washington, DC, November.

- 2019b. "Prepayment Monitoring Report: Third Quarter 2019." Washington, DC, December 9.

—. 2019c. "Annual Housing Report." Washington, DC, October 30.

Financial Crisis Inquiry Commission. 2011. The Financial Commission Inquiry Report. Washington, DC: U.S. Government Printing Office.

Fisher, Lynn, Nobert Michel, Patrick Lawler, Tobias Pinto, Alex Pollock, and Peter Wallison. 2018. "An Administrative Approach to Reducing GSEs' and FHA's Footprint, Including an Analysis of the Nature of Housing Appreciation and the Linkage with Housing Finance Policy, the GSEs' and FHA's Pro-Cyclical Support of Housing Boom, the Role Played by the QM 'Patch.' " American Enterprise Institute, August 17.

Frame, W. Scott, Andreas Fuster, Joseph Tracy, and James Vickery. 2015. "The Rescue of Fannie Mae and Freddie Mac.” Journal of Economic Perspectives, vol. 29, no. 2, pp. 25-52. Available at https://doi.org/10.1257/jep.29.2.25

Freddie Mac. 2020. Form 10-K: Annual Report for the Fiscal Year Ended December 31, 2019. Washington, DC: United States Securities and Exchange Commission.

Fuster, Andreas, and James Vickery. 2015. "Securitization and the Fixed-Rate Mortgage." The Review of Financial Studies, vol. 28, no. 1, pp. 176-211. Available at https://doi.org/10.1093/rfs/hhu060

Ghent, Andra C., Ruben Hernandez-Murillo, and Michael T. Owyang. 2014. "Did Affordable Housing Legislation Contribute to the Subprime Securities Boom?” Federal Reserve Bank of St. Louis Working Paper 2012-005D. Available at https://doi.org/10.2139/ssrn.2038577

Goodman, Laurie, Ed Golding, and Michael Neal. 2019. "Fast Prepayments of VA Mortgages Are Increasing Costs to Veteran and FHA Mortgage Borrowers." Urban Institute, June.

Goodman, Laurie, and Jun Zhu. 2013. "The GSE Reform Debate: How Much Capital is Enough?” Urban Institute, October 24. 
Housing Finance Policy Center. 2020. "Housing Finance at a Glance: A Monthly Chartbook.” Urban Institute, January.

Kanojia, Akash, and Meghan Grant. 2016. "The TBA Market: Effects and Prerequisites," in Susan M. Wachter and Joseph Tracy, eds., Principles of Housing Finance Reform. Philadelphia: University of Pennsylvania Press.

Layton, Don. 2019. "How Deep Is the 'Economic Moat' Around the Two GSEs?” Joint Center for Housing Studies of Harvard University, Industry Perspectives, September.

Mortgage Bankers Association. 2017. GSE Reform: Creating a Sustainable, More Vibrant, Secondary Mortgage Market. Washington, DC: Mortgage Bankers Association.

Mosser, Patricia C., Joseph Tracy, and Joshua Wright. 2013. "The Capital Structure and Governance of a Mortgage Securitization Utility." Federal Reserve Bank of New York, Staff Report No. 644, October.

Parrott, Jim, Lew Ranieri, Gene Sperling, Mark Zandi, and Barry Zigas. 2016. "A More Promising Road to GSE Reform." Urban Institute, March 31.

Scharfstein, David and Phillip Swagel. 2016. "Legislative Approaches to Housing Finance Reform," in Susan M. Wachter and Joseph Tracy, eds., Principles of Housing Finance Reform. Philadelphia: University of Pennsylvania Press.

Stegman, Michael, and Phillip Swagel. 2018. "The Role of Duty to Serve in the Secondary Mortgage Market.” Milken Institute, July.

Vickery, James, and Joshua Wright. 2013. "TBA Trading and Liquidity in the Agency MBS Market." Federal Reserve Bank of New York, Economic Policy Review, vol. 19, no. 1, pp. 1-18. Available at https://doi. org/10.2139/ssrn.2324222

Wachter, Susan M. 2018. "Credit Risk Transfers, Informed Markets, and Securitization.” Federal Reserve Bank of New York, Economic Policy Review, vol. 24, no. 3, pp. 117-137. Available at https://doi.org/10.2139/ssrn.3100404

Wachter, Susan M., and Patricia A. McCoy. 2016. "A New Coalescence in the Housing Policy Debate?” Penn Wharton Public Policy Initiative, vol. 4, no. 6.

Wachter, Susan M., and Joseph Tracy. 2016. "Introduction," in Susan M. Wachter, and Joseph Tracy, eds., Principles of Housing Finance Reform. Philadelphia: University of Pennsylvania Press.

Wallison, Peter J. 2011. "Dissenting Statement," in The Financial Crisis Inquiry Report. Washington, DC: U.S. Government Printing Office.

Wallison, Peter J., and Edward J. Pinto, eds. 2018. "The Taxpayer Protection Housing Finance Plan: Gradually Winding Down Fannie Mae and Freddie Mac and Improving the FHA.” American Enterprise Institute, January 23. 